\title{
SOCIAL AND EDUCATIONAL MOVEMENTS AND THEIR IMPACT ON THE SCHOOL BUILDING PROGRAMME IN BUDAPEST IN AROUND 1900
}

\author{
Los movimientos sociales y educativos y su impacto en el programa \\ de construcción escolar en Budapest alrededor de 1900
}

\section{Imre Garai ${ }^{\beta}$ and András Németh $\gamma$}

Reception date: 25/03/2020 • Acceptation date: 06/10/2020

Abstract: In our current study, we focus on school building program of Géza Bárczy who was the mayor of the Hungarian capital in the first two decades of the twentieth century. From the mid of the nineteenth century, Budapest had experienced a rapid development thanks to social and economic changes. The city council felt impelled to reflect on growing needs of the population of the city, therefore it launched a complex social program including renovating and building new school headquarters.

Our main findings suggest that newly emerged school buildings stood in the frontier of different endeavours. Their structure and inner elements were influenced by pedagogues and intellectuals who were staunch supporters of reform pedagogy aiming at salvaging children from the harmful effects caused by traditional schooling. Furthermore, school buildings also represented the pride of the nation and the hope that talent members of future generations can preserve the fundamentals of the nation. It seems that the school building program of this area entailed these endeavours and even tried to reflect on them.

Keywords: Bárczy era; Reform pedagogy; Life Reform; school buildings; Budapest.

\footnotetext{
${ }^{\alpha}$ We would like to dedicate our paper to the memory of Miklós Mann (1935-2020) who devoted several books and articles to the history of education of Budapest.

${ }^{\beta}$ Historical, Theoretical and Comparatice Research Group. Eötvös Loránd University, Faculty of Education and Psychology. Kazinczy street 23-27. Budapest H-1075. Hungary, garai.imre@ppk.elte. hu (D) https://orcid.org/0000-0001-7129-7807

$\gamma$ Historical, Theoretical and Comparatice Research Group. Eötvös Loránd University, Faculty of Education and Psychology. Kazinczy street 23-27. Budapest H-1075. Hungary. nemeth.andras@ppk. elte.hu (D) https://orcid.org/0000-0001-9770-9830
}

How to cite this article: Garai, Imre and András Németh. "Social and educational movements and their impact on the school building programme in Budapest in around 1900". Historia y Memoria de la Educación 13 (2021): 249-284 
Resumen: En este estudio nos centramos en el programa de construcción de escuelas de Géza Bárczy, quien fue alcalde de la capital húngara en las dos primeras décadas del siglo XX. Desde mediados del siglo XIX, Budapest había experimentado un rápido desarrollo gracias a los cambios sociales y económicos. El ayuntamiento se sintió impulsado a reflexionar sobre las crecientes necesidades de la población de la ciudad, por lo que lanzó un complejo programa social que incluía la renovación y construcción de nuevas instalaciones escolares.

Nuestros principales hallazgos sugieren que los edificios escolares recién surgidos se encontraban en la frontera de diferentes esfuerzos. Su estructura y elementos internos fueron influenciados por pedagogos e intelectuales que fueron firmes defensores de la pedagogía reformista que busca salvar a los niños de los efectos dañinos causados por la escolarización tradicional. Además, los edificios escolares también representan el orgullo de la nación y la esperanza de que los miembros talentosos de las generaciones futuras puedan preservar sus fundamentos. Parece que el programa de construcción de escuelas de esta zona implicó estos esfuerzos e incluso trató de reflexionar sobre ellos.

Palabras claves: Era Bárczy; pedagogía de la reforma; movimiento de vuelta a la naturaleza; construcciones escolares; Budapest.

\section{INTRODUCTION}

Towards the end of the nineteenth century, the Hungarian capital was among those metropolises in Central and Southern Europe that experienced rapid urbanisation. The pattern of development in Budapest was typical, although there were pronounced differences between the capital and the surrounding rural areas. This resulted in Budapest becoming almost exclusively the cultural centre of the country, which was experiencing its heyday at the turn of the century. During this period, the liberal mayor István Bárczy, who directed affairs in the capital between 1906 and 1918, implemented reforms that affected the infrastructure and functionality of spaces in the city. A broad school building programme was also launched during his tenure as mayor of the city. ${ }^{1}$

\footnotetext{
${ }^{1}$ Németh, András, "Nemzetközi tudományfejlödési és recepciós tendenciák a század első hazai pedagógiai lexikonjaiban", Magyar Pedagógia, 100 (2000): 187-208; Németh, András, "Die Lebensreform und ihre pädagogische Rezeption in Ungarn: Lebensreform und Bildungsreform", in ed. Németh, András, Skiera Erenhard, and Mikonya, György, Reformpädagogik und Lebensreform in Mitteleuropa: Ursprünge, Ausprägung und Richtungen, länderspezifische Entwicklungstendenzen (Budapest: Gondolat Kiadó, 2006), 56-86.
} 
In this paper, changes in school buildings and spaces dedicated for education purposes in Hungary will be discussed along to five aspects. First and foremost, theoretical background of the 'space turn' in science of education and thus in history of pedagogy will be discussed. Secondly, a brief overview of the development of modern schools and architecture of school buildings will be presented according to the relevant international literature. Additionally, it seems inevitable to discuss the international trends of the most important social and pedagogical reform movements, which provided the background of the change of perception of spaces in schools. Related to these reform movements, those ideas that had an impact on both of the form, arrangement and equipment of school buildings and also on the Hungarian education policy and pedagogical reform endeavours that determined the inner equipment and the architecture of school building are also an essential part of this study. Finally, at the end of the paper some examples will be shown to highlight the main features of school buildings in the Hungarian capital in the Bárczy-era.

\section{SPACE IN THE CONTEXT OF HISTORICAL PEDAGOGY}

Since the end of the 1980s, cultural and social sciences have been reinterpreting space as a result of the postmodern turns (linguistic, iconic, time). The spatial turn describes the recently arouse scientific interest in space not only from the point of view of geography, ${ }^{2}$ but also from sociology, cultural studies, literary studies, ${ }^{3}$ theology and organization theory. ${ }^{4}$ Henri Lefebvre's (1901-1991) classic volume, the production de

\footnotetext{
2 Soja, Edward, Postmodern geographies: the reassertion of space in critical social theory (London: Verso, 1989); Bachmann-Medick, Doris, Cultural Turns: neuorientierungen in den Kulturwissenschaften (Reinbek bei Hamburg: Rowohlt-Taschenbuch-Verlag, 2007); Spatial Turn: das Raumparadigma in den Kultur- und Sozialwissenschaften. ed. Döring, Jörg and Thielmann, Tristan (Bielefeld: Transcript Verlag, 2008), 219-221.

${ }^{3}$ Agotai, Dorris, Architekturen in Zelluloid: der filmische Blick auf den Raum (Bielefeld: Transcript Verlag, 2007); Günzel, Stephan, Raum: eine kulturwissenschaftliche Einführung (Bielefeld: Transcript Verlag, 2017); Raumtheorie. Grundlagentexte aus Philosophie und Kulturwissenschaften. ed. Dünne, Jörg, Günzel, Stephan, Doetsch, Hermann, und Lüdeke, Roger (Frankfurt am Main: Suhrkamp, 2006); Raum und Bewegung in der Literatur: die Literaturwissenschaften und der Spatial Turn. ed. Hallet, Wolfgang and Neumann, Birgit (Bielefeld, Transcript Verlag, 2009); Löw, Marina, Raumsoziologie (Frankfurt am Main: Suhrkamp, 2001).

${ }^{4}$ Jörg and Thielmann, "Spatial Turn"; Cf. Smeyers, Paul and Depaepe, Marc, "Exploring a Multitude of Spaces in Education and Educational Research", in ed. Smeyers, Paul, Depaepe, Marc, and
} 
l'espace introduced the notion of spatial turn and drove in its usage in the social and cultural sciences. ${ }^{5}$ Lefebvre aimed at defining all kind of spaces regardless to the fact whether the examined spaces are abstract or real, social or individual. According to his concept, spaces could be defined and separated in a triad, which is comprised of spatial practices, representations of space and spaces of representation or conceived, living space.

Spatial practices (pratique spatiale) refers to practices of physical transformation of the environment that result in occurrence of perceived spaces. Representations of space (représentation de l'espace) is also part of this group. It determines the theories and interpretations of spaces in sciences, architecture, urbanism and education. The last element of the triad is the spaces of representations (espaces de l'représentation), which helps to identify how spaces are perceived and dominated by different groups of the society by using wide range of techniques including ideologies or physical power. ${ }^{6}$

Lefebvre's theory facilitated research endeavours aimed at investigating the complexity of different spatial processes. Even though each element of the triad has to be examined in details in historically specific investigations and thus these elements do not offer a universal scheme for examining spaces, still Lefebvre inspired numerous research projects. Manuel Castells was one of the first researches who applied Lefebvre's concept in an analysis (The City and the Grassorts), which aimed at exploring the historical aspects of urban transformations. ${ }^{7}$ Edward Soja interpreted the Lefebvre introduced theory from a postmodern point of view in his Thirdspace. ${ }^{8}$

Keiner, Edwin Educational Research: The Importance and effects of Institutional Spaces (London-New York: Springer, 2013), 1-10.

${ }^{5}$ Lefebvre, Henry, Production de l'espace (Paris: Anthropos, 1974).

${ }^{6}$ Németh, András, “A néptanítói szakismeretek konstrukciós folyamatai a 20. század elején - a néptanítók enciklopédiája példája alapján (1911-1915)”, Magyar Pedagógia, 113 (2013): 101-118.

${ }_{7}^{7}$ Casstels, Manuel, The City and the Grassroots: a Cross-cultural Theory of Urban Social Movements (Berkeley: University of California Press, 1983).

${ }^{8}$ See Stanek, Eukasz, Methodologies and Situations of Urban Research. Re-reading Henri Lefebvre's 'The Production of Space', Zeithistorische Forschungen/Studies in Contemporary History, Online-Ausgabe, 4 (3), (2007), 461-465, consulted on 1 July 2020. URL: https://zeithistorische-forschungen.de/3-2007/4715 
As a result of an increasing international attention to space and place, it became a popular examination topic in the science of education and thus it was also put in the spotlight in the field of history of education. ${ }^{9}$ This research approach in the history of education helps to reveal the culturally specific patterns of space in the context of culturally divergent ideas about childhood, education or community. Furthermore, it also offers a peculiar insight into the different technical innovations related to schools. ${ }^{10}$ By using the power aspect of spaces during the analysis, historical perspectives ${ }^{11}$ of the development of school architecture could be analysed. Additionally, the development and transformation of traditional school buildings and spaces into innovative solutions (open-air, and others types of schools related to the progressive education) were also incorporated into this approach. Bourdieu and Foucault inspired further the examination of spaces in education ${ }^{12}$ and their papers helped

\footnotetext{
${ }_{9}$ Rißler, Georg, Bossen, Andrea, and Blasse, Nina, "School as space: spatial alterations, teaching, social motives, and practices", Studia paedagogica, 19 (4), (2014), 146-159, consulted on 1 July 2020, doi: $10.5817 /$ SP2014-4-7

10 Baker, Lindsay, (2012), A History of School Design and its Indoor Environmental Standards, 1900 to Today (National Institute of Building Sciences, Washington, 2012); Burke, Catharine and Grosvenor, Ian, School (London: Reaktion Books, 2008); Gislason, Neil, "Building paradigms: Major transformations in school architecture (1798-2009)", Alberta Journal of Educational Research, 55 (2009): 230-248; Göhlich, Michael, "Schulraum und Schulentwicklung. Ein historischer Abriss", in ed. Böhme, Jeanette Schularchitektur im interdisziplinären Diskurs. Territorialisierungskrise und Gestaltungsperspektiven des schulischen Bildungsraums (Wiesbaden: VS Verlag für Sozialwissenschaften, 2009), 89-102; Jelich, Franz-Josef and Kemnitz, Heidemarie Die pädagogische Gestaltung des Raums. Geschichte und Modernität. Jahrestagung der Sektion Historische Bildungsforschung in der Deutschen Gesellschaft für Erziehungswissenschaft (Bad Heilbrunn: Klinkhardt, 2003); Lange, Hermann, Schulbau und Schulverfassung der frühen Neuzeit. Zur Entstehung und Problematik des modernen Schulwesens (Weinheim: Verlag Julius Beltz, 1967); Schmidt, Rudolf, "Die geschichtliche Entwicklung des Volksschulbaus in Deutschland", Paedagogica Historica, 7 (1967): 519-550; Schmidt, Rudolf, "Die geschichtliche Entwicklung des Volksschulbaus in Deutschland", Paedagogica Historica, 8 (1968): 153-193; Seaborne, Malcolm Vivian John The English school: its architecture and organization 1370-1870 (London: Routledge \& Kegan Paul, 1971); Seaborne, Malcom Vivian John, Schools in Wales 1500-1900. A social and architectural history (Denbigh: Gee and Son, 1992); Seaborne, Malcolm Vivian John and Lowe, Roy The English school. Its architecture and organization (Toronto: University of Toronto Press, 1977).

${ }^{11}$ Göhlich, Michael, Die pädagogische Umgebung. Eine Geschichte des Schulraums seit dem Mittelalter (Weinheim: Deutscher Studien Verlag, 1993); Hnilica, Sonja, "Schulbank und Klassenzimmer Disziplinierung durch Architektur", in ed. Egger Rudolf and Hackl, Bernd, Sinnliche Bildung? Pädagogische Prozesse zwischen vorprädikativer Situierung und reflexivem Anspruch (Wiesbaden: Springer Fachmedien, 2010), 141-162; Markus, Thomas A., "Early Nineteenth Century School Space and Ideology", Paedagogica Historica: International Journal of the History of Education, 32 (1996): 9-50.
}

12 Alkemeyer, Thomas and Rieger-Ladich, Markus, "Symbolische Gewalt im pädagogischen Feld. Überlegungen zu einer Forschungsheuristik", in ed. Schmidt, Robert and Woltersdorf, Volker Symbolische Gewalt. Herrschaftsanalyse nach Pierre Bourdieu (Konstanz: UVK-Verlag, 2008), 103-124; 
to find a link between school culture and space by analysing both the material presence of school architecture and spatial practices, designs and spatial paradigms. ${ }^{13}$

\section{INTERNATIONAL BACKGROUND}

There were many prerequisites for the emergence of modern cities, with modernisation being comparatively possibly the most important. Modernisation can be understood as a mechanism that consisted of several components, such as industrialisation, professionalization, urbanisation, and the development of modern infrastructure and administration. It was universal from two perspectives. Firstly, it transformed the internal structures of newly emerged nation states pertaining to all aspects, from the economic to the cultural. Secondly, modernisation did not stop at the borders of the U.S. or Great Britain, but reached different parts of Europe and other continents at different times. ${ }^{14}$

This process of modernization in Western Europe, North America and also in Central and Eastern Europe required rapid adaptation to the new conditions that prevailed in the later phases of the $19^{\text {th }}$ century. Significant changes took place in the economy and the industrial development let to urbanization through the technological progress. State administrations became involved in the planning and management of industrial, economic and social changes. This phenomenon resulted in the increasing scrutiny of state administration over almost every aspect of life of their citizens including family life, work, schooling and even

\footnotetext{
Kajetzke, Laura and Schroer, Markus, "Schulische Mobitektur. Bauen für Bildung", in ed. Böhme, Jeanette Schularchitektur im interdisziplinären Diskurs. Territorialisierungskrise und Gestaltungsperspektiven des schulischen Bildungsraums (Wiesbaden: VS Verlag für Sozialwissenschaften, 2009), 299312; Rieger-Ladich, Markus and Ricken, Norbert, "Macht und Raum: Eine programmatische Skizze zur Erforschung von Schularchitekturen", in ed. Böhme, Jeanette Schularchitektur im interdisziplinären Diskurs. Territorialisierungskrise und Gestaltungsperspektiven des schulischen ildungsraums (Wiesbaden: VS Verlag für Sozialwissenschaften, 2009), 186-203.

${ }_{13}$ Böhme, Jeanette and Herrmann, Ina, "Schulraum und Schulkultur", in ed. Böhme, Jeanette Schularchitektur im interdisziplinären Diskurs. Territorialisierungskrise und Gestaltungsperspektiven des schulischen Bildungsraums (Wiesbaden: VS Verlag für Sozialwissenschaften, 2009), 204-220; Böhme, Jeanette and Herrmann, Ina, Schule als pädagogischer Machtraum. Typologie schulischer Raumentwürfe (Wiesbaden: VS Verlag für Sozialwissenschaften, 2011).

14 Kalocsai, Péter, “A városi közlekedés modernizációja Magyarországon (1867-1914)”, in ed. H. Németh, István, Szívós, Erika, and Tóth, Árpád, A város és társadalma: Tanulmányok Bácskai Vera tiszteletére (Budapest: Hajnal István Kör - Társadalomtörténeti Egyesület, 2011), 62-77.
} 
leisure activities. Since almost all aspects of life were documented, it provided excellent opportunity for exerting control over citizens.

Striving for control over all aspects of life, however also resulted in introducing norms in all territories of social life that led to predictable changes in the society and force individuals to comply with the socio-politico aims of the state. Rapid progress of sciences also contributed to this process. The occurrence of modern medicines and psychiatry with the intention of quantifying and measuring social phenomena amplified the intention of planning social changes. These developments were extremely important from the viewpoint of the old elites of states in an area, in which the emergence of mass democracies with new nation-state ideologies and emancipation of uneducated people through expanding the eligibility of voting could endanger the traditional leadership. ${ }^{15}$

Modernisation affected both the population of the cities and the formation of city spaces. The physical and symbolic demolition of medieval walls in municipalities contributed to the replacement of old city structures with new ones. The extension of citizenship to all inhabitants was key to generating economic growth and a demand for services. Furthermore, eradicating the dysfunctional constructions inherited from earlier centuries freed up new spaces within municipalities that could be used for economic or public purposes. ${ }^{16}$

The separation of spaces in cities for different purposes was also an important element in the emergence of modern municipalities. The division of the private sphere from the workplace and their physical detachment from each other resulted in the emergence of districts and functional spaces. As a consequence of conscious urban planning, the central parts of metropolises were dedicated to hosting administrative offices, commercial businesses and the residences of the elite. At the same time, the outskirts of the cities became industrial areas and residential zones for the less affluent social classes. ${ }^{17}$

\footnotetext{
15 See Burke and Grosvenor, School, 28-29.

16 Hanák, Péter, "Polgárosodás és urbanizáció: Polgári lakáskultúra Budapesten a 19. században”. Történelmi szemle, 27 (1984): 123-144.

17 Hanák, "Polgárosodás és urbanizáció”, 123-124.
} 
The spatial divergence of the different parts of modern cities was facilitated by the modern road system and the new symbolic functionality of public places and buildings. Avenues and boulevards were built not only with representative functions in mind: they also connected the different parts of the city, providing the population with physical and social mobility. ${ }^{18}$ Moreover, the public spaces and buildings maintained a sense of unity through their historicising architectural style in the case of Central European cities. Although these dedicated public spaces commemorated historical events, they served the purely political aim of expressing the glory of the nation, thereby becoming common places of memory. In the case of capitals, this function was vital since they represented the unity of the nation, despite their evolution into cosmopolitan cities. ${ }^{19}$

Paris and London were role models for city administrations across the old continent that aspired to transformation into modern metropolises. Urban development in these two cities followed a pre-planned pattern, and high standards were achieved in terms of the modernisation of public services and infrastructure. In Central Europe, however, Vienna - as the capital of the Habsburg Empire - also had an influence on the development of major cities throughout the region. Buda and Pest (united in terms of both their administration and their name in 1873) began their urbanisation progress lagging behind the major European metropolises. $^{20}$

At the end of the nineteenth century, urbanisation processes accelerated in Central Europe, and later in Southern Europe. Municipal administrations began to modernise their urban infrastructure and public services, including health conditions, modern lighting and energy technologies such as gas and electricity supply. Public transport systems were also significantly improved. The development of metropolises in the region primarily followed the earlier examples of urbanisation programmes in the English, French and Austrian capitals. In the background of these initiatives, comprehensive care for the city's inhabitants was linked with a high professional ethos on the part of the

\footnotetext{
${ }^{18}$ Hanák, "Polgárosodás és urbanizáció", 124-125.

19 Gyáni, Gábor, "Kollektív emlékezet és a tér nagyvárosi kultusza”, in ed. Gyáni, Gábor A történelem mint emlék(mü) (Budapest: Kalligram, 2016), 109-118.

${ }^{20}$ Hanák, "Polgárosodás és urbanizáció”, 127-131; Gyáni, “Kollektív emlékezet”, 110.
} 
administrative officials and progressive technology. This can clearly be perceived as a paradigm shift in terms of city administration and governance, reflecting the increasing complexity of the social and industrial development taking place in major cities. ${ }^{21}$

\section{THE DEVELOPMENT OF MODERN SCHOOL SYSTEMS AND THEIR NEW SPACES}

As a consequence of the industrialisation in Europe and North America, the school as an institution and the spaces dedicated for education purposes within it were also transformed. The evolvement of modern state apparatus restructured confessional type of schools into bureaucratic education systems, in which the role of churches faded away to the benefit of the state, which exerted control over the education of future citizens. ${ }^{22}$ However, the development of mass education also resulted in challenges that were addressed by careful planning of buildings and the transformation of roles of staff of schools that led to emergence of teaching profession. Thus the occurrence of modern state education stimulated the planning associated with school affairs. As a result, municipal school buildings were constructed, which were considered as symbols of modernization and urban pride.

Modern schools were carefully planned by designers and architects in order to provide school professionals and pupils with special places dedicated for preparing students for the challenges posed by the transformation of the society. Public building projects were a kind of competition between designers and architects who had to submit their plans to local councils. During the planning phase they had to take into account different regulations, which limited their imagination. Regulators paid attention to the location of planned schools, economical aspects of the construction works, traditions of the local community and special needs of children in different age and thus different types of schools (elementary, secondary schools). Regulations in Germany, for instance, even set

\footnotetext{
${ }^{21}$ Bairoch, Paul and Goertz, Gery, "Factors of Urbanization in the Nineteenth Century Developed Countires: A Descriptive and Economic Analysis”, Urban Studies, 23 (1986): 285-305.

22 Popkewitz, Thomas S., "The Double Gestures of Cosmopolitanism and Comparative Studies of Education" in ed. Cowe, Robert and Kazamias, Andreas M. International Handbook of Comparatice Education (London-New York: Springer, 2009), 385-401.
} 
the standards in square feet or square meters of classroom space per pupil and the number of washbasins and toilets that have to be provided for the school staff and students. The inauguration of a new school building was a major event in the community. Consequently, there was an official opening celebrated in the presence of politicians and representatives of the churches. Members of the public including parents, residents of the neighbourhood also attended and even the local press reported on the event. ${ }^{23}$

According to Burke and Grosvenor, spaces and furniture of new schools expressed the special attention of the state towards the students intellectual and physical development. Chairs and tables were adapted to the needs of the children in order to keep their body healthy despite the long time period they spent sitting in schools every day. The idea behind this adaption of the furniture of the school was to make the schools fit for the expectations and the needs of the children in order to transform them into citizens. Although school buildings were characterized by the classrooms, prevailing pedagogical ideas also resulted in occurrence of spaces with social functions, e.g. halls and playgrounds. ${ }^{24}$

Besides the social and physical education of schools, the ultimate aim of these new institutions was to provide the citizens with basic literacy. Additionally, the construction of a national identity was based on the learning of a common language in countries where more than one language coexisted. This function was outlined by the physical representation of schools that determined the landscape of municipals. This representation also alluded to the fact that children were separated from the society in order to give them special skills, by which they can contribute to the progress of the whole of the society. Thus, mass education institutionalized the separation of children from the rest of the society. Furthermore, the prevalence of compulsory education in Europe and North America contributed to prevalence of Western-type of education systems in the colonies, by which Western powers scrutinized the population of the conquered territories in Africa and Asia.

\footnotetext{
${ }_{23}$ Burke and Grosvenor, School, 54-57.

${ }^{24}$ Burke and Grosvenor, School, 58-62.
} 
By the beginning of the $20^{\text {th }}$ century, modern school became universalized spaces specially designed for exerting control over the development of children. Professional progress of teachers also evolved along instructing pupils in different subjects and convert them into citizens by implementing strict regulations and discipline. The control took place in school buildings and school spaces and amplified by the furniture and the equipment. This material environment influenced the development of the students and made them an object of school culture. Division of children and their sequential promotion along to achievements in studies also highlight the control function of schools. Additionally, the design of classrooms made possible the unidirectional communication of cultural knowledge including the values and norms of the society. Thus, school spaces became instruments to reassert the school culture and thereby the social order through regulating the intellectual, physical and social advancement of pupils. ${ }^{25}$

\section{SOCIAL AND EDUCATIONAL REFORM MOVEMENTS}

In around 1900, a consensus developed on the need to attenuate the consequences arising from high population density in the cities of Central Europe. According to the reform initiatives, measures were needed in order to replace the old housing stock, which had not yet been equipped with modern sanitary technology; to bring light and air into the different districts of the cities; and to connect them together as a whole by means of technological advancements and carefully planned public spaces.

Various critical social reform movements, such as Life Reform (Lebensreform), played a significant role in these initiatives as a design model. Within this intellectual paradigm, the British concept of the garden city, which emerged at the end of the nineteenth century, was crucial. It was interpreted first and foremost as the greening and opening up of the inner parts of cities. Such critical movements were perceived as an opportunity to forge a paradigm shift in everyday life and agricultural conditions in order to overcome the crises caused by rapid technological development. ${ }^{26}$

\footnotetext{
25 Burke and Grosvenor, School, 62-64.

${ }_{26}$ Vincze, Beatrix, “A kertmotívum Németh László pedagógiai és életreform koncepciójában”, in ed. Németh, András and Pukánszky, Béla, Gyermekek, tanárok, iskolák - egykoron és ma (Budapest: Eötvös Kiadó, 2017), 189-203.
} 
The goal of achieving an existential shift for the sake of salvaging the future of society was a common characteristic of the various Life Reform movements. By following ideas such as returning to nature and pursuing the principles of a healthy lifestyle, individuals were empowered to follow a new way of living and improve their environment at the same time. Conscious and disciplined consumption could contribute to minimising the unwanted consequences of living in industrialised social reality. Thus, we use the term Life Reform to refer to the complexity and totality of various reform movements (such as the above-mentioned garden city movement, as well as soil reform, anti-alcohol, naturopathy and physical culture improvement movements). In fact, in the background of these reform movements was a barely veiled hostility towards the existing industrial civilisation. The newly coined and popular phrase escaping from the city indicated that these movements aimed to restore the traditional relationship between nature and humankind, which could lead to the achievement of new quality and new attitudes towards work and the relationship with God. ${ }^{27}$

The new prophets of Life Reform expected the improvement of society to be achieved through individual and collective actions in everyday life. By pursuing the new life principles, a new humankind could emerge from the created harmonious world, free from physical and mental diseases and disorders. ${ }^{28}$ In addition, salvation theories emphasised the following of a natural lifestyle, by means of which the redemption of the modern human was conceivable. These theories were associated with socio-political, artistic, religious, and even metropolis reform movements. ${ }^{29}$ Consequently, cities were perceived as the remnants of industrial development that could be saved by individual (self-reform) and collective endeavours (the reshaping of city spaces in order to provide them

\footnotetext{
${ }^{27}$ Krabbe, Wolfgang R., "Die Lebesreformbewegung", in ed. Buchholz, Kai et alii Die Lebensreform. Entwürfe zur Neugestaltung von Leben (Darmstadt: Häusser Verlag, 2001), 25-30; Krabbe, Wolfgang R., Gesellschaftsreform durch Lebensreform: Strukturmerkmale einer sozialre-form-erischen Bewegung im Deutschland der Industrialisierungsperiode (Göttingen: Vandenhoeck und Ruprecht, 1974).

${ }_{28}$ Küenzlen, Gottfried, Der Neue Mensch: Eine Untersuchung zur säkularen Religionsgeschichte der Moderne (München: Fink, 1994).

29 Vincze, Beatrix, “A földi édenhez vezető 'harmadik utas' elméleti és gyakorlati modellek a két világháború közötti Magyarországon", in ed. Németh András and Vincze Beatrix, Továbbélö utópiák - magyar életreform-törekvések és nemzetközi recepciós hatások (Budapest: Gondolat Kiadó, 2017), 35-57.
} 
with new functionality and the restoration of a connection with nature by means of planting). ${ }^{30}$

According to Skiera, these reform initiatives grew from fertile soil, which comprised a multitude of quasi-religious worldviews and secular doctrines of salvation. In terms of their origin, pseudoscientific theories, as well as political, spiritual, and even mythological elements can be identified. ${ }^{31}$ Since these movements were critical of civilisation and considered education to be a key element in transforming the deteriorating industrialised world, common ground emerged with progressive education. These pedagogical movements had also developed a critical attitude towards the impacts of industrialisation on schools, thus their relationship to technological advancement was ambiguous. Although the role of modern inventions was acknowledged in reform pedagogical schools, these movements aimed to salvage the child from the industrialised approach to education that prevailed in modern nation states. Life Reform and Progressive Education (Reformpädagogik) thus became mutually dependent. New educational concepts could take effect in a social environment that functioned according to the principles of Life Reform, and, vice versa, the elements of Life Reform were reflected in many ways in Reform Pedagogies in order to create a new society in the not so distant future that could surpass industrial civilisation by means of a return to nature.

Consequently, educational reform movements that were related to Life Reform formulated numerous basic principles for the school and school building programmes at the turn of the nineteenth and twentieth centuries. Among these sets of rules, the so-called hygienic discourse can be emphasised as one of the most important trends. The argumentation can be traced back to the Darwinian theory of the development of species, including humankind. According to this popular belief in the nineteenth century, any kind of environmental factor could result in the

\footnotetext{
${ }^{30}$ Barlösius, Eva, Naturgemäße Lebensführung: Zur Geschichte der Lebensreform um die Jahrhundertwende (Frankfurt und New York: Campus, 1997).

31 Skiera, Ehrenhard, Reformpädagogik in Geschichte und Gegenwart: Eine kritische Einführung (München und Wien: Oldenbourg, 2003); Skiera Ehrenhard, "Über den Zusammenhang der Lebensreform und Reformpädagogik", in ed. Skiera, Ehrenhard Németh, András und Mikonya György Reformpadagogik und Lebensreform in Mitteleuropa - Ursprünge: Ausprägung und Richtungen (Budapest: Gondolat Kiadó, 2006), 22-47.
} 
development of an illness that could lead to the extinction of the entire species.

The idea of normality also played a crucial role in the dissemination of the principles of the hygiene movement among various strata of society. Normality was a prevalent idea in the late nineteenth century and influenced the school hygiene movement, which used normality as a core term in reshaping concepts concerning schools as organisations, students, and their shared spaces - namely, the school buildings (for example, the normal posture of students, normal clothing, normal school classrooms, and normal furnishings and equipment). ${ }^{32}$ At the very beginning of the twentieth century, empirical psychology and child and youth studies also influenced the public discourse and thus political decision-making processes concerning education and school buildings. ${ }^{33}$

Anti-modern reform movements, including Life Reform, had an enormous impact on the critical reform elite and teaching staff of schools in the capital. At the beginning of the new century, there was a common belief that the time had now come to achieve significant results in terms of altering existing social and economic conditions. Intellectuals in the critical elite and teachers became convinced that schools were endangering the natural development of children, thus they needed to take preliminary steps in order to create the necessary conditions within the institutions for the healthy development of students. They depicted themselves as the saviours of children by forming new conditions within the institutions.

\footnotetext{
32 Sarasin, Philipp and Tanner, Jakob, Physiologie und industrielle Gesellschaft: Studien zur Verwissenschftlichung des Körpers im 19. und 20. Jahrhundert (Frankfurt am Main: Shurkamp, 1998), 20; Sarasin, Philipp, Reizbare Maschinen: Eine Geschichte des Körpers 1765-1914 (Frankfurt am Main: Shurkamp, 2001), 17.

33 Cf. Freyer, Michael, Das Schulhaus: Entwicklungsetappen im Rahmen der Geschichte des Bauernund Bürgerhauses sowie der Schulhygiene (Passau: Wissenschaftsverlag Rothe, 1998); Kost, Franz, "Die Normalisierungder Schule. Zur Schulhygienebewegung in der zweiten Hälfte des 19. Jahrhunderts", Zeitschrift für Pädagogik, 30 (1983): 769-782; Stroß, Annette, Pädagogik und Medizin: Ihre Beziehungen in 'Gesundheitserziehung' und wissenschaftlicher Pädagogik 1779-1933 (Weinheim: Beltz, 2000); Freyer, Jürgen, Alte Eugenik und Wohlfahrtspflege: Entwertung und Funktionalisierung der Fürsorge vom Ende des 19. Jahrhunderts bis zur Gegenwart (Freiburg: Breisgau, 1991); Oelkers, Jürgen, (1998) "Psychologie, Pädagogik und Schulreform im 19. Jahrhundert", in ed. Sarasin Phillipp und Tanner Jakob Physiologie und industrielle Gesellschaft: Studien zur Verwissenschaftlichung des Körpers im 19 und 20. Jahrhundert (Frankfurt am Main: Surkamp, 1998), 245-285; Hopf, Caroline, Die experimentelle Pädagogik: Empirische Erziehungswissenschaft in Deutschland am Anfang des 20. Jahrhunderts (Bad Heilbrunn: Julius Klinkhardt, 2004), 27-29.
} 
Protecting children from the harmful impacts of civilisation and ensuring their natural and healthy development became an imperative for advocates of these new intellectual trends. This led to new semantics for the expression of their ideas. Expressions such as child protection, healthy child and natural development acquired an almost sacred meaning. A new kind of language emerged, in which child protection and children's right to healthy development became a normative and descriptive element. This alteration in language usage and professional attitude is underlined by the fact that these new semantic elements were incorporated into teachers' professional ethos and became a regulatory principle in their professional forums of communication. In this context, schools were perceived as social spaces in which new ideas could be disseminated and thereby social advancement achieved. ${ }^{34}$

A new wave of openness, flexibility and informality in pedagogical practice began to have an impact on the new social and educational reform movements. In this process, the material environment of schools also played a decisive role in enabling new forms of pedagogy to be flourished and the focus to be switched from the teacher to the child. As new ideas on hygiene and pedagogy spread throughout Europe in the first decade of the twentieth century, it became obvious that traditional design of school buildings and the furniture did not meet with the needs of children. ${ }^{35}$

International pedagogical exhibitions and study visits helped the exchange and dissemination of new ideas in the late nineteenth century. As a result of increasing attention to the inner design and functionality of schools, ventilation was one element that was set in the focus. Ventilation systems were outdated and the poor air quality could result in severe headaches and irritability, which undermined the health of children and the efficacy of teaching. Therefore, it was perceived a major threat to both the staff and the children. Furthermore, a number of studies had been published in various countries discussing the harmful effects of school furniture and showing that the normal arrangement of desks,

\footnotetext{
${ }^{34}$ Cf. Tenorth, Heinz-Elmar, "Der Beitrag der Erziehungswissenschaft zur Professionalisierung pädagogischer Berufe” in ed. Apel, Hans Jürgen, Horn, Klaus-Peter, Lundgreen, Peter, Sandfuchs, Uwe Professionalisierung pädagogischer Berufe im historischen Prozeß (Bad Heilbrunn: Klinkhardt, 1999), 429-461.

35 See Burke and Grosvenor, School, 68-69.
} 
where pupils were fixed in their places for long periods of time, led to muscle fatigue and deformation. Maria Montessori criticised heavily the prevalent types of desks and declared that its usage was a clear sign of the negligence of the children's needs. Similarly, experts and school activists drew attention to the inappropriate and harmful interior design of schools in the U.S. Dark, poorly designed playrooms, inadequate equipment and tiny space per capita in classrooms made a significant proportion of schools almost unfit for teaching. ${ }^{36}$

Dilapidated interior of schools threatened the future of nations and therefore urged governments across Europe to facilitate constructing new school that could comply with new standards and thus improve the well-being of children. According the Crowley, an English school expert, the best way to enhance the quality of infrastructure of schools designed for children of the ordinary public was to observe and implement the prevailing practices of other countries. His volume, The Hygiene of School Life entailed not only suggestions for school building practices and equipment but it also paid attention to make recommendations for organising teaching activities in a way that could be effective and take into account the needs of children. He outlined in his book that aesthetic aspects should be considered less important when it comes to planning of school buildings. By suggesting that beauty and hygiene were compatible with each other, he demonstrated that the simplicity could be the principle that should have been followed during the planning. ${ }^{37}$

School of tomorrow expressed the essence of reform endeavours that aimed at altering spaces and equipment of schools. Advocates of social and school reforms drew attention to the importance of fresh air and light in education and fostered a Europe-wide interest towards the concept and design of open-air schools. In these schools, sunlight was perceived as a symbol of freeing pupils from deprived circumstances of slums and the constant threat posed by tuberculosis. In 1907, the first open-air school of England was set up in Borstall Wood in London. Additionally, crèches and kindergartens were founded, in which bright and well-ventilated rooms were combined with progressive methods that were inspired by child-centred education entailing playful learning and

\footnotetext{
${ }_{36}$ Burke and Grosvenor, School, 67-70.

37 Burke and Grosvenor, School, 69-70.
} 
developing the personality and identity of children. Other directions of the new school movement declared a break with the architectural heritage in the spirit of the school of tomorrow. According to its slogan, the school of tomorrow would be "the garden city of children' where the monstrous 'heavy walls, the terrible gates, the hard playground, the sunless and huge classrooms [...] the awful and grim corridors' would be 'swept away' and children freed from the darkness of the 'prison house"'. ${ }^{38}$ The state remained tolerant towards these types of progressive pedagogical experiments, since early childhood learning was the territory of the education where expectations of the advocates of the new schools and the society were not far from each other. ${ }^{39}$

\section{LIFE REFORM, EDUCATIONAL REFORM AND SCHOOL CONSTRUCTION IN THE BÁRCZY ERA}

In the professional and emancipatory endeavours of primary school teachers, Life Reform elements and pedagogical reform ideas were linked in Hungary. The significance of elementary school teachers as a professional group grew steadily in the last decades of the nineteenth century. ${ }^{40}$ Their importance is underlined by the fact that they played a crucial role in the reforms that affected school buildings in the Bárczy era.

Bárczy was mayor of the Hungarian capital between 1906 and 1918. Although he had earned a degree in law, he became convinced that education could contribute to easing social tensions. Before his inauguration as mayor, he had chaired the Public Education Department of the General Assembly of Budapest for almost half a decade. Under his supervision, the department had created the concept of the folk house, which could serve as a centralised body of city governance to address social issues in the capital. ${ }^{41}$ As mayor, he incorporated earlier social reform ideas into his agenda and organised a circle of intellectuals with

\footnotetext{
38 Quoted from Burke and Grosvenor, School, 74.

39 Burke and Grosvenor, School, 76-77.

40 Németh, András, “A modern középiskolai tanári és tanítói szakmai tudástartalmak kibontakozásának történeti folyamatai”, Pedagógusképzés, 11 (2007): 5-26.

41 Sipos, András, Várospolitika és városigazgatás Budapesten, 1890-1914 (Budapest: Budapest Főváros Levéltára, 1996), 241-242.
} 
the aim of providing support for the transformation of the governance of cultural and social institutions in the capital.

The intellectuals who surrounded Bárczy believed that the governance of a modern city should not only involve administrative tasks related to the everyday lives of the inhabitants, but should also reflect the aspirations of citizens who wanted to experience progress by means of social mobility. In order to achieve this goal, they created a reform laboratory of socio-political decision making. ${ }^{42}$ This idea was prevalent in other cities in the region thanks to new movements that influenced both intellectuals and politicians. The promise of social progress and rapid industrial and infrastructural development turned these cities into cosmopolitan metropolises. ${ }^{43}$

The reforms and infrastructural investments of the Bárczy era helped transform Budapest into a modern, cosmopolitan city. New buildings with representative and public functions emerged during this period, illustrating the outstanding developments that took place under Bárczy's leadership. Schools and residential buildings from this area are still referred to as the heritage of the mayor and the Monarchy. During these twelve years, public transport, lighting, the municipal system and its administration were also modernised and taken into public ownership and supervision. ${ }^{44}$ Moreover, numerous small apartments and schools were constructed as part of the mayor's social agenda. In the 1910s, a library network was established to promote public and adult education. The Library of the Capital City became a quasi-scientific institution and provided intellectual support for the mayor with its collection of urbanistic and social literature. ${ }^{45}$

\footnotetext{
42 Sipos, András, "Bárczy István és Karl Lueger: két polgármester a századforduló Monarchiájában"., in ed. Szvoboda Dománszky, Gabriella, Urbanizáció a dualizmus korában: Konferencia Budapest egyesítésének 125. évfordulója tiszteletére a Budapesti Történeti Múzeumban (Budapest: Budapesti Történeti Múzeum, 1999), 53-66.

${ }_{43}$ Gatner, Eszter and Hein-Kirchner, Heidi (2017), "Emerging cities": Knowledge and Urbanization in Europe's Borderlands 1880-1945”, Journal of Urban History, 4 (1991): 575-586.

${ }^{44}$ Sipos, Várospolitika és városigazgatás, 165-175.

${ }_{45}$ Sipos, Várospolitika és városigazgatás, 84; Németh, András and Pukánszky, Béla, "Life Reform Efforts in the Austro-Hungarian Monarchy and Their Impact on Hungarian Cultural and Pedagogical Reforms", Paedagogica Historica, (2019) consulted on 20. February 2020, doi: 10.1080/00309230.2019.1586736; Németh, András and Nagy, Andrea, "Life Reform and Reform Pedagogy in Hungary", Sodobna Pedagogika: Journal of Contenmporary Educational Studies, 70 (2019): 192-205.
} 
Primary school teachers and the teaching staff at teacher training institutes played an important role in the reforms affecting schools and school buildings. Due to the fact that they had developed a strong professional competence by this time, they felt impelled to express their professional views and wanted to see their suggestions implemented in schools. In its heyday at the turn of the century, child research and the modern pedagogical-psychological movement supported them in their efforts to reform schools. Teachers reflected on the results achieved in new scientific fields and incorporated these elements into their professional knowledge.

Between 1911 and 1915, the first pedagogical encyclopaedia series was published for primary school teachers. The Encyclopaedia of National Education was intended to summarise all the necessary knowledge in the scientific discipline of pedagogy and school administration. In doing so, it also shaped the professional knowledge of primary school teachers. ${ }^{46}$ Moreover, the encyclopaedia provided elementary school teachers with a detailed overview of the various school reforms of that period. Special attention was paid to the New School movement in England, and mention was also made of national pedagogical reform trends that shared a common ground with new methodological approaches or that promised a new type of schooling (Abbotsholme, Arbeitsschule, Landerziehungsheim, Pfadfinder, Waldschule). ${ }^{47}$ The names of authors and pedagogical intellectuals such as Tolstoy, Ellen Key, Ruskin and Berthold Otto appeared in the encyclopaedia as keywords. In addition, the volumes make reference to Dewey, whose School and Society had been translated and published in Hungary in 1912.48

The Hungarian Society for Child Research was founded in 1906 by László Nagy (1857-1931), a teacher at the State Primary School Training Institute, and his colleagues. The society provided further training and courses for already practising teachers in order to spread child-centred

\footnotetext{
${ }^{46}$ Németh, András and Pukánszky, Béla, "Magyar reformpedagógiai törekvések a XX. század első felében”, Magyar Pedagógia, 99 (1999): 245-262.

${ }^{47}$ Depaepe, Marc, Zum Wohl des Kindes? Pädologie, pädagogische Psychologie und experimentelle Pädagogik in Europa und in den USA, 1890-1940 (Weinheim: Deutscher Studien Verlag, 1993), 340347.

${ }^{48}$ Németh, András, A magyar neveléstudomány fejlödéstörténete (Budapest: Gondolat Kiadó, 2002), 175-176.
} 
pedagogical views. Furthermore, it supported teachers in their efforts to familiarise themselves with these intellectual trends by publishing books and journals concerning children. Nagy became editor-in-chief of the society's journal A gyermek (The Child) in 1907. The periodical provided a basis for cooperation between teachers influenced by the reform intellectual trends and the leadership of Budapest. ${ }^{49}$

However, cooperation in this regard was not limited to just one journal. It had begun with Népmüvelés (National Education), which also promoted educational reforms. Launched in 1906, the periodical existed until 1918 (from 1912, its name was changed to Új Élet [New Life]), and was a forum for communication among educators in the capital. In addition, it promoted the cultural policy measures and educational reform initiatives of the Bárczy-programme, since the mayor himself participated in preparations for the launch of the journal. The periodical offered publication opportunities not only for Hungarian representatives of child research and experimental psychology, but also for representatives of the different directions of the Hungarian Life Reform movement. Authors included intellectuals committed to anarchism and syndicalism, as well as disciples of Tolstoy and numerous followers of the different approaches of the Hungarian Secession. Likewise, representatives of the artists' colony in Gödöllo" 50 played an important role in publication activity during the first period of the journal following its launch. ${ }^{51}$

The Capital City Pedagogical Seminary also played an important role in forging a link between Life Reform and Reform Pedagogies. It was established in 1912 under the direction of Ödön Weszely, a university associate professor of pedagogy and director of a secondary school for the natural sciences (Realschule). ${ }^{52}$ It offered advanced studies for already practising elementary school teachers and helped new graduates of elementary teacher training institutes to become familiar with the peculiarities of school-related affairs in the capital, and with elementary school teaching. The fact that newly trained teachers could not be

\footnotetext{
49 Németh, András, "Egyetemi neveléstudomány - reformpedagógia - magyar oktatásügyi reformok", Magyar Pedagógia, 104 (2004): 39-55.

${ }^{50}$ A minor city located 30 kilometres from Budapest to the east.

${ }^{51}$ Németh, "Die Lebensreform", 85.

52 Mann, Miklós, Budapest oktatásügye 1873-2000 (Budapest: Önkonet, 2002), 72-73.
} 
appointed to vacant positions unless they had attended the seminary underlines the importance of the new institution in the educational life of Budapest. ${ }^{53}$ The classes offered at the institute provided participants with advanced knowledge in child studies, physics, law, economics, philosophy and pedagogy. ${ }^{54}$ It became something of a spiritual centre for pedagogues who aimed to advance their knowledge of the latest developments in school-related intellectual trends and research. Thus not only elementary school teachers, but also educators from other types of schools, including secondary school teachers, also attended training sessions at the institute. ${ }^{55}$

\section{THE NEW SCHOOL BUILDING PROGRAMME IN THE HUNGARIAN CAPITAL}

Even though Budapest had more school buildings with advanced infrastructure than municipals in the countryside in the nineteenth century, still the local government of the capital had to hire buildings and chambers in order to provide the increasingly growing number of students with room for education purposes. Expansion of the school infrastructure could not keep up with the growth of population. Despite the regulation of the $38^{\text {th }}$ Act of the Parliament in 1868, which determined that size of primary school classes could be comprised of 60 students, 80 or even more pupil attended in one class around the turn of the century. According to a report assigned in 1906, only one square meter space had one pupil in the overcrowded schools. Heating was available inside the classrooms but halls were without it. Restrooms were rarity in the buildings and their condition were unsatisfactory in most of the cases. ${ }^{56}$

During Bárczy's tenure as mayor, Budapest dedicated almost a quarter $(23.1 \%)$ of its annual budget to cultural purposes, a significantly higher amount than other capitals in the region, such as Vienna (14.1\%)

\footnotetext{
${ }_{53}$ Németh, András, Weszely Ödön (Budapest: Országos Pedagógiai Könyvtár és Múzeum, 1990), 13; Kocsis, Mihály, "Weszely Ödön munkássága a Magyar Királyi Erzsébet Tudományegyetemen", Iskolakultúra, 9 (1996): 114-125.

${ }^{54}$ Mann, Budapest oktatásügye, 73-74.

${ }_{55}$ Németh, "Egyetemi neveléstudomány", 45.

${ }^{56}$ Sanda, István Dániel, “Az iskola-egészségügy és a tanulási környezet korszerüsödése Magyarországon - a szadforduló körüli évtizedekben”, Pedagógiatörténeti Szemle, 4 (2016): 86-105.
} 
and Berlin (9.8\%). ${ }^{57}$ This provided the necessary financial resources for an extensive school building programme after 1909. Within three years, 36 new school buildings were constructed. During this period, 55 buildings were reconstructed or newly built, with a total of 967 classrooms. Service apartments were also added to school buildings in order to ease the housing crisis affecting young primary school teachers. ${ }^{58}$ Special attention was given to installing heating systems, classroom furniture, roof terraces and functional schoolyards with dedicated playgrounds. Besides constructing new school buildings and renovating their infrastructure, the city council also established special workshops dedicated to producing school equipment and teaching materials. ${ }^{59}$

School buildings were at the focus of various endeavours related to child welfare. The buildings were designed by prominent architects of the era. Moreover, classrooms and dedicated spaces for common activities were constructed according to the suggestions of school doctors, in order to comply with strict hygiene standards. These spaces had to be sufficiently large to provide children with the necessary room for free movement, and equipped with windows to let fresh air and natural light into the school rooms. ${ }^{60}$ Doctors, together with officials from the city council and the Ministry of Public Education, determined the regulations for the size of the rooms and circulation areas, such as corridors, stairwells and playgrounds. ${ }^{61}$

In 1905, the school doctor and health teacher subcommittee of the National Public Health Organization prepared a proposal for an ideal model school. Although the model school was never built, the proposal was an unquestionable sign of the increasing attention to the well-being of school children and influenced the construction of the 36 school buildings that were built as part of the Bárczy-programme. According to the proposal, the model school would have entailed eight classrooms and only 40 pupils could have attended in one class. Six square metres would have been dedicated to each pupil, which consisted of two square

\footnotetext{
57 Mann, Budapest oktatásügye, 59.

58 Németh, “Die Lebensreform”, 81; Mann, Budapest oktatásügye, 60.

59 Németh, “Die Lebensreform”, 81; Mann, Budapest oktatásügye, 58.

60 Sanda, “Az iskola-egészségügy”, 99-100.

${ }^{61}$ Németh, “Die Lebensreform”, 81-82.
} 
metres space in the class, three square metres in an open-air yard and one square meter open-air playground covered by roof. The proposal even paid attention to aspects of the choice of the location of the model school. Authors declared that the headquarters of the school should have been placed far away from main roads and highways in order to keep the air of the school fresh and healthy and to prevent pupils from encountering the unintended consequences of social phenomena prevailing in the neighbourhood of busy locations. ${ }^{62}$

In addition to the choice of the location of schools, much attention was paid to the interiors of the school rooms. In case of school buildings that were built as a result of the Bárczy-programme, the interiors including frescoes, statues and furniture, were designed by members of the Hungarian artists' colonies in Gödöllö and Kecskemét. ${ }^{63}$ These interior design elements not only reflected the need for rooms dedicated to particular members of staff or for special purposes (auditoriums, toilets, sports halls, bathrooms and apartments for the director and caretakers), but also took into account the principles of subject teaching and the division of pupils into different classes. As frontal teaching was the prevalent method during this era, classrooms were adapted to its requirements during the planning and construction phases. ${ }^{64}$

As far as the style of the architecture of the school buildings is concerned, several types of school buildings could be separated from each other. Generally, all the buildings tended to evoke historical antecedents thus elements of the Gothic, Renaissance, Baroque and Classicist style can be found on the headquarters. Nevertheless, majority of facades of headquarters of schools that were built as part of the Bárczy-programme tended to show the impact of Historicism and Secession. Additionally, Folk Secession also can be discovered due to the fact that architects of the buildings were convinced following the advice of John Ruskin and William Morris that Hungarian arts can be reformed through the rediscovery and usage of Hungarian folk motives. ${ }^{65}$

\footnotetext{
${ }^{62}$ Sanda, "Az iskola-egészségügy", 99.

${ }^{63}$ A municipality located more than 85 kilometres from Budapest to south east.

${ }^{64}$ Németh, "Die Lebensreform", 83.

${ }^{65}$ Sanda, István Dániel (2014): "Iskolaépület-típusok és életreform-motívumok a Bárczy-korszak iskoláiban”, in ed. Németh, András, Pukánszky, Béla and Pirka, Veronika Továbbélöutópiák-reformpedagógia
} 
Interestingly, even the local curriculum reflected the achievements of the school building programme. In 1913, a local curriculum was introduced in Budapest schools. It was more specific than the national curriculum and enabled students to advance further in their studies compared to their peers in the countryside, who followed a different curriculum determined by the ministry. Essentially, the new school buildings - with their advanced infrastructure influenced by various intellectual trends and endeavours - created a unique pedagogical space that enabled progressive primary school teachers, who had been trained at the Seminary, to achieve a higher pedagogical quality. ${ }^{66}$

The original plans for the school building programme comprised three types of school. The first were elementary schools for boys and girls with 12 classrooms, divided equally between the two sexes. This type of school also had a gymnasium and a kindergarten for between 60 and 180 children. The second type was dedicated to students attending the upper four classes of elementary school, between the ages of 10 and 14. In these type of schools, not only classrooms, gym and service rooms for the staff were built but special classrooms dedicated for scientific subjects (physics, chemistry), handicrafts and arts (drawing, music) were also located for the first time in history of education in Hungary. ${ }^{67}$ The third type was a commercial school for boys. The separation of boys and girls was a consequence of moral values based on public consensus, which thus influenced the structure of the school system. However, most elementary schools were common institutions, although separate entrances and classes ensured the isolation of the two groups. Even the schoolyards were completely separate. Gymnasiums and other special facilities could be used only alternately, for moral and ethical reasons.

Size of standard classrooms were ten metres long, their width was six metres and the height of rooms were for metres, thus 65 square metres were the total size of the rooms. Ten school desks followed each other in one aisle and usually three aisles were created in one classroom with 60 pupils. Consequently, one pupil had one square meter and 4,3

\footnotetext{
és életreform a 20. század els $₫$ felében (Budapest: Gondolat Kiadó, 2014), 214-302.

${ }^{66}$ Mann, Budapest oktatásügye, 60-61.

${ }_{67}$ Sanda, "Iskolaépület-típusok", 216-217.
} 
cubic metres. In case of special classrooms, their size was one third of a standard classroom. As far as the extent of other service rooms is concerned, the room of the teaching stuff was equal with a classroom in its size. On the contrary, the office of the head of the school was half of the capacity of a standard classroom. Similarly, the room of school doctors was one third of a standard classroom. Service rooms were put in the ground floor in the proximity of the main gate in order to be available easily by all members of the school. ${ }^{68}$

As for the size of Gyms, they were 20 metres long, 20 metres width and their height were six metres. Puttying these rooms on the ground floor would have taken up too much space and, therefore it had been an inadequate solution due to the fact that properties were expensive. Consequently, gyms were usually placed on the first floor or at the top level of the building in order to save space. By finding a location for gyms inside the building, more space could be used for creating an open-air yard. According to the regulations, 1,5 square metres open-air spaces per pupil should have been provided for all students. This prescription would have required large properties. In order to reduce the expenses and comply with the regulations, yards were created in the ground floor level and it was supplemented by establishing roof terraces with playgrounds on the top floor. ${ }^{69}$

As hygienic discourse had a significant impact on the planning of new school buildings, special attention was dedicated to sanitary facilities. Therefore, toilets were placed at all storeys in order to maintain the hygiene of pupils and the school staff. Entrance of the toilets were located far from any classrooms. Washbasins were available in all restrooms to avoid the spread of diseases. Likewise, in order to maintain the personal hygiene and enhance the hygiene awareness of students, school baths were created on experimental basis. Due to the fact that architects did not find proper European solutions that could be applied to all schools in Hungary and their construction work were expensive, school baths were available just in a few newly built schools. ${ }^{70}$

\footnotetext{
68 Sanda, István Dániel, “A pedagógiai terek vizsgálata. Különös tekintettel a XX. századi magyar iskolára” (Doctoral thesis, Budapest ELTE PPK Neveléstudományi Doktori Iskola, 2009), 126-127.

69 Sanda, A pedagógiai terek, 127-128.

70 Sanda, A pedagógiai terek, 128-129.
} 
The school buildings combined hygienic and ergonomic aspects with unlimited pedagogical functionality. This development was a result of the new pedagogical tendencies, such as child research and Reform Pedagogy, which affected the planning and construction of the headquarters of educational institutions. Schools were thus perceived as workplaces with high social significance - a perception based on the work school concept that originated in the Reform Pedagogic movements. The related educational guidelines were aimed at achieving new social quality by reforming the existing institutes of mass education..$^{71}$

Essentially, school buildings as pedagogical spaces incorporated the pedagogical and political endeavours shaped by Reform Pedagogies and Life Reform elements. The political decision makers simply understood and processed the increasing reform demands of the new intellectuals and tried to incorporate their proposals when shaping the future of schooling. This was facilitated by the common belief, derived from Enlightenment philosophy, that the students attending school today would be the citizens of the immediate future. Improved schooling methods would therefore ultimately lead to a brighter future.

Among interior equipment and furniture of schools, school desks had always been given special attention in the columns of various pedagogical journals. By the time of the Bárczy-programme, a discourse had been taking place for decades about the question of using proper benches in schools. Since widely varied types of school desks were used in European countries, several brands were implemented in schools in order to gain experience about their functionality for future decision about implementing one type to all schools throughout the country. Finally, a German type of school bench was found suitable to be implemented in the capital. According to the German licence, Hungarian furniture facilities manufactured the new benches in nine sizes. The first size was dedicated for six and seven years old school children and the highest, ninth size was used in commercial schools because they were fit for old young adults between age of sixteen and seventeen. ${ }^{72}$

\footnotetext{
${ }^{71}$ Németh, András, "A reformpedagógia gyermekképe: A szent gyermek mítoszától a gyermeki öntevékenység funkcionális gyakorlatáig”, Iskolakultúra, 4 (2002): 21-32.

72 Sanda, A pedagógiai terek, 139.
} 
Education also became a priority in nation state building processes, thus the significance of education was also reflected in the school buildings. The new headquarters of educational institutes not only integrated the pedagogical trends shaped by Life Reform and Reform Pedagogies, but also represented the pride and glory of the nation. These architectural achievements were seen as proof of the success of the nation and expressed the hope that the development of the country would continue by means of the training of talented citizens.

In the spirit of Reform Pedagogies, schools and their buildings were to serve the mental and physical education of both the nation and the younger generations. Protected children, with a solid moral outlook and free from the physical weaknesses caused by inappropriate and outdated pedagogy, could set the faith of the community on a new course. This considerable overlap between nation state building, Reform Pedagogies and Life Reform elements was given expression in the aesthetic appearance of the school buildings, which were often decorated with Hungarian motifs that were deeply rooted in Hungarian folklore. Thus the school buildings not only represented a dedicated space for educational purposes, but also hinted at a symbolic space where the renewal of society might be achieved. ${ }^{73}$

This renewal, however, was hindered by the outbreak of the First World War. After the end of fighting and the revolutions between 1918 and 1919, the education continued among profoundly difficult circumstances. The infrastructure of the schools was in a dilapidated condition thanks to their usage as either hospitals for injured soldiers or barracks for units heading towards the trenches. Due to the damaged infrastructure of schools, many students were forced to continue their education in overcrowded classrooms. Problems occurred with the heating and lighting systems. The lack of resources resulted in unintended intervals in the school year. After the revolutions and the consolidation of the political power, the city council of the capital could not continue the renewal programme of school buildings immediately. It had to hire

\footnotetext{
${ }^{73}$ Cf. Jellich, Franz-Josef und Kemnitz, Heidemarie, Die pädagogische Gestaltung; Kemnitz, Heidemarie, "Denkmuster und Formensprache pädagogischer Architekturen im ersten Drittel des 20. Jahrhunderts", in ed. Crotti, Claudia und Osterwalder, Fritz Das Jahrhundert der Schulreformen: Internationale und nationale Perspektiven, 1900-1950 (Bern, Stuttgart, Wien: Haupt, Verlag, 2008), 251-281.
} 
buildings and rooms again and the so called barrack schools ${ }^{74}$ that were built for an interim period in the Bárczy era until they were replaced by new buildings, remained in usage. The new political course continued the school building programme after a loan was given to Hungary by the League of Nations in 1924. The new programme was not just influenced by Reform pedagogy and Life Reform movements but is was also determined by the new wave of nationalism that swept across Central-Eastern Europe right after the war and the emergence of new national states. ${ }^{75}$

\section{CONCLUSION}

In the present paper, we have focused on the school building programme in the Hungarian capital during the Bárczy era. Our research has shown that school buildings stood at the frontier of various endeavours. Architects, doctors, politicians and intellectuals with connections to the critical reform movement influenced the construction of new buildings and the renovation of existing ones. The new school headquarters can be perceived not only as spaces dedicated to pedagogical purposes, but as special spaces with a symbolic reference to the renewal of society as a whole. This aspect was underlined by the use of folklore motifs and interior design elements created by members of artists' colonies.

In the background of the emergence of new school buildings, with their explicit pedagogical aims and their implicit efforts to achieve social change, Life Reform and Reform Pedagogies were the prevailing intellectual trends. Normality, hygiene discourse, and child and youth studies were aimed at the salvation of children, and thus at the transformation of society as a whole, by creating schools that reflected their needs. The new pedagogies were interwoven with anti-modernisation concepts and shared the same view of the harmful effects of the emergence of modern civilisation, with the impersonal way of life in modern cities and dehumanising working conditions. The underlying goal was

\footnotetext{
74 Sanda, A pedagógiai terek, 138.

75 Mann, Miklós, “Budapest oktatásügye a két világháború között”, Educatio, 14 (2005): 120-136.
} 
to nurture a new generation that would rediscover life qualities that had been effaced by modernisation. ${ }^{76}$

István Bárczy, as an official involved in educational affairs and later as mayor, devoted particular attention to improving social and economic conditions in the Hungarian capital. He and the counsellors surrounding him believed that education could make a significant contribution to achieving advances in these two areas. Although the new school buildings incorporated the ideas of critical movements, they also served to express national pride and the infrastructural development of the city, by means of which the social deprivation of its poorer inhabitants could be alleviated. Essentially, the school building programme was just one element in his reform agenda, the aim of which was to modernise the infrastructure of Budapest and transform it into a flourishing city. Thus, the reformed schools, with their improved external and interior features, ultimately contributed to promoting a modified approach to modernisation.

Investigating further the motifs and the architecture of school buildings in the Hungarian capital in the Bárczy era by using iconographical approach might help to reveal hidden elements of the connections between Life Reform endeavours the reform pedagogy and the formation of modern nation state school systems. Examination of these unrevealed elements could be crucial to have a better understanding of the intellectual and social movements that shaped the formation processes of the school systems around the turn of the $19^{\text {th }}$ and the $20^{\text {th }}$ century in Central and Eastern Europe.

\section{Notes on the authors}

IMRE GARAI earned his PhD with his first book in 2014 and he is about to be promoted to associate professor thanks to finishing his second book in 2019. Both of his books related to the professionalization processes of

\footnotetext{
76 Vincze, Beatrix, “Theoretische und praktische Modelle des zum irdischen Eden führenden 'Drittem Weges' in der Zwischenkriegszeit in Ungarn”, in ed. Németh, András, Stöckl, Claudia and Vincze, Beatrix, Survival of Utopias - Weiterlebnede Utopien: Life Reform und Progressive Education in Austria and Hungary - Lebensreform und Reformpädagogik in Österreich und Ungarn (Franfurt am Main: Peter Lang Verlag, 2017), 41-53.
} 
secondary school teachers in the 19th and 20th century in Central-Eastern Europe. In his first volume, he presented new results related to the history of Eötvös József Collegium, which is a teacher training boarding school in Hungary. By using the critical approach of the professionalization theories, he gave a detailed analysis over the professional function of Secondary Teacher Training Institution and Secondary School Teacher Examination Committee located at the University of Budapest between 1862 and 1919 in his second volume. Besides investigating the history of professionalization of secondary school teachers, he also had publications concerning history of education sciences before and after the 2nd Word War in Hungary, memories of primary and secondary teachers and development of nation state education systems in Central Europe.

ANDRÁs NÉmeth is a full professor of Historical, Theoretical and Comparative Pedagogy in the Faculty of Education and Psychology at Eötvös Loránd University in Budapest. The general and historical education, the history of life reform and models of "new education", the history of the discipline and the history of the reception European intellectual trends in the Central European and Hungarian educational sciences stand in the focus of his research activities and research interest. He has been chairing of the subcommission for the history of education at the Hungarian Academy of Sciences since 1997. His scientific activities can be accessed in details here: https:/curriculum78.webnode.hu/

\section{REFERENCES}

Agotai, Dorris. Architekturen in Zelluloid: der filmische Blick auf den Raum. Bielefeld: Transcript Verlag, 2007.

Alkemeyer, Thomas and Markus Rieger-Ladich. "Symbolische Gewalt im pädagogischen Feld. Überlegungen zu einer Forschungsheuristik". In Symbolische Gewalt. Herrschaftsanalyse nach Pierre Bourdieu, edited by Robert Schmidt and Woltersdorf, Volker, 103-124. Konstanz: UVK-Verlag, 2008.

Bachmann-Medick, Doris. Cultural Turns: neuorientierungen in den Kulturwissenschaften. Reinbek bei Hamburg: Rowohlt-Taschenbuch-Verlag, 2007.

Bairoch, Paul and Gery Goertz. "Factors of Urbanization in the Nineteenth Century Developed Countires: A Descriptive and Economic Analysis”, Urban Studies 23 (1986): 285-305. 
Baker, Lindsay. A History of School Design and its Indoor Environmental Standards, 1900 to Today. Washington: National Institute of Building Sciences, 2012.

Barlösius, Eva. Naturgemäße Lebensführung: Zur Geschichte der Lebensreform um die Jahrhundertwende. Frankfurt und New York: Campus, 1997.

Böhme, Jeanette and Ina Herrmann. Schule als pädagogischer Machtraum. Typologie schulischer Raumentwürfe. Wiesbaden: VS Verlag für Sozialwissenschaften, 2011.

Böhme, Jeanette and Ina Herrmann. "Schulraum und Schulkultur". In Schularchitektur im interdisziplinären Diskurs. Territorialisierungskrise und Gestaltungsperspektiven des schulischen Bildungsraums, edited by, Böhme, Jeanette, 204-220. Wiesbaden: VS Verlag für Sozialwissenschaften, 2009.

Burke, Catharine and Ian Grosvenor. School. London: Reaktion Books, 2008.

Castells, Manuel. The City and the Grassroots: a Cross-cultural Theory of Urban Social Movements. Berkeley: University of California Press, 1983.

Depaepe, Marc. Zum Wohl des Kindes? Pädologie, pädagogische Psychologie und experimentelle Pädagogik in Europa und in den USA, 1890-1940. Weinheim: Deutscher Studien Verlag, 1993.

Spatial Turn: das Raumparadigma in den Kultur-und Sozialwissenschaften, edited by Döring, Jörg and Thielmann, Tristan. Bielefeld: Transcript Verlag, 2008.

Raumtheorie. Grundlagentexte aus Philosophie und Kulturwissenschaften, edited by Dünne, Jörg, Günzel, Stephan, Doetsch, Hermann, und Lüdeke, Roger. Frankfurt am Main: Suhrkamp, 2006.

Freyer, Jürgen. Alte Eugenik und Wohlfahrtspflege: Entwertung und Funktionalisierung der Fürsorge vom Ende des 19. Jahrhunderts bis zur Gegenwart. Freiburg: Breisgau, 1991.

Freyer, Michael. Das Schulhaus: Entwicklungsetappen im Rahmen der Geschichte des Bauern- und Bürgerhauses sowie der Schulhygiene. Passau: Wissenschaftsverlag Rothe, 1998.

Gatner, Eszter and Heidi Hein-Kirchner. "Emerging cities": Knowledge and Urbanization in Europe's Borderlands 1880-1945”. Journal of Urban History 43, no. 4 (1991): 575-586.

Gislason, Neil. "Building paradigms: Major transformations in school architecture (1798-2009)”. Alberta Journal of Educational Research, 55, no 2 (2009): 230-248.

Göhlich, Michael. Die pädagogische Umgebung. Eine Geschichte des Schulraums seit dem Mittelalter. Weinheim: Deutscher Studien Verlag, 1993.

Göhlich, Michael. "Schulraum und Schulentwicklung. Ein historischer Abriss". In Schularchitektur im interdisziplinären Diskurs. Territorialisierungskrise und Gestaltungsperspektiven des schulischen Bildungsraums, edited by 
Böhme, Jeanette, 89-102. Wiesbaden: VS Verlag für Sozialwissenschaften, 2009.

Günzel, Stephan. Raum: eine kulturwissenschaftliche Einführung. Bielefeld: Transcript Verlag, 2017.

Gyáni, Gábor, "Kollektív emlékezet és a tér nagyvárosi kultusza”, In A történelem mint emlék(mü), edited by Gyáni, Gábor, 109-118. Budapest: Kalligram, 2016.

Raum und Bewegung in der Literatur: die Literaturwissenschaften und der Spatial Turn, edited by Hallet, Wolfgang and Neumann, Birgit. Bielefeld, Transcript Verlag, 2009.

Hanák, Péter. "Polgárosodás és urbanizáció: Polgári lakáskultúra Budapesten a 19. században”. Történelmi szemle, 27, no .1-2 (1984): 123-144.

Hnilica, Sonja. "Schulbank und Klassenzimmer - Disziplinierung durch Architektur”. In Sinnliche Bildung? Pädagogische Prozesse zwischen vorprädikativer Situierung und reflexivem Anspruch, edited by Egger, Rudolf and Hackl, Bernd, 141-162. Wiesbaden: Springer Fachmedien, 2010.

Hopf, Caroline. Die experimentelle Pädagogik: Empirische Erziehungswissenschaft in Deutschland am Anfang des 20. Jahrhunderts. Bad Heilbrunn: Julius Klinkhardt, 2004.

Jelich, Franz-Josef and Kemnitz, Heidemarie. Die pädagogische Gestaltung des Raums. Geschichte und Modernität. Jahrestagung der Sektion Historische Bildungsforschung in der Deutschen Gesellschaft für Erziehungswissenschaft. Bad Heilbrunn: Klinkhardt, 2003.

Kajetzke, Laura and Markus Schroer. "Schulische Mobitektur. Bauen für Bildung”. In Schularchitektur im interdisziplinären Diskurs. Territorialisierungskrise und Gestaltungsperspektiven des schulischen Bildungsraums, edited by Böhme, Jeanette, 299-312. Wiesbaden: VS Verlag für Sozialwissenschaften, 2009.

Kalocsai, Péter. “A városi közlekedés modernizációja Magyarországon (18671914)”. In A város és társadalma: Tanulmányok Bácskai Vera tiszteletére, edited by H. Németh, István, Szívós, Erika, and Tóth, Árpád, 62-77. Budapest: Hajnal István Kör - Társadalomtörténeti Egyesület, 2011.

Kemnitz, Heidemarie. "Denkmuster und Formensprache pädagogischer Architekturen im ersten Drittel des 20. Jahrhunderts”. In Das Jahrhundert der Schulreformen: Internationale und nationale Perspektiven, 1900-1950, edited by Crotti, Claudia und Osterwalder, Fritz, 251-281. Bern, Stuttgart, Wien: Haupt, Verlag, 2008.

Kocsis, Mihály. "Weszely Ödön munkássága a Magyar Királyi Erzsébet Tudományegyetemen”. Iskolakultúra, 9, no 8 (1996): 114-125.

Kost, Franz. "Die Normalisierungder Schule. Zur Schulhygienebewegung in der zweiten Hälfte des 19. Jahrhunderts”. Zeitschrift für Pädagogik, 29, no. 5 (1983), 769-782. 
Krabbe, Wolfgang R. Gesellschaftsreform durch Lebensreform: Strukturmerkmale einer sozialre-form $\neg$ erischen Bewegung im Deutschland der Industrialisierungsperiode. Göttingen: Vandenhoeck und Ruprecht, 1974.

Krabbe, Wolfgang R. "Die Lebesreformbewegung”. In Die Lebensreform. Entwürfe zur Neugestaltung von Leben, edited by Buchholz, Kai, 25-30. Darmstadt: Häusser Verlag, 2001.

Küenzlen, Gottfried. Der Neue Mensch: Eine Untersuchung zur säkularen Religionsgeschichte der Moderne. München: Fink, 1994.

Lange, Hermann. Schulbau und Schulverfassung der frühen Neuzeit. Zur Entstehung und Problematik des modernen Schulwesens. Weinheim: Verlag Julius Beltz, 1967.

Löw, Marina. Raumsoziologie. Frankfurt am Main: Suhrkamp, 2001.

Markus, Thomas A. "Early Nineteenth Century School Space and Ideology". Paedagogica Historica: International Journal of the History of Education, 32, no. 1 (1996): 9-50.

Mann, Miklós. Budapest oktatásügye 1873-2000. Budapest: Önkonet, 2002.

Mann, Miklós. “Budapest oktatásügye a két világháború között”. Educatio, 14, no. 1 (2005): 120-136.

Németh, András. “Egyetemi neveléstudomány - reformpedagógia - magyar oktatásügyi reformok”. Magyar Pedagógia, 104, no. 1 (2004): 39-55.

Németh, András. "Die Lebensreform und ihre pädagogische Rezeption in Ungarn: Lebensreform und Bildungsreform”. In Reformpädagogik und Lebensreform in Mitteleuropa: Ursprünge, Ausprägung und Richtungen, länderspezifische Entwicklungstendenzen, edited by Németh, András, Skiera Erenhard, and Mikonya, György, 56-89. Budapest: Gondolat Kiadó, 2006.

Németh, András. A magyar neveléstudomány fejlödéstörténete. Budapest: Gondolat Kiadó, 2002.

Németh, András. “A modern középiskolai tanári és tanítói szakmai tudástartalmak kibontakozásának történeti folyamatai”. Pedagógusképzés, 11, no. 1-2 (2007): 5-26.

Németh, András. "Nemzetközi tudományfejlődési és recepciós tendenciák a század első hazai pedagógiai lexikonjaiban”. Magyar Pedagógia, 100, no. 2 (2000): 187-208.

Németh, András. “A néptanítói szakismeretek konstrukciós folyamatai a 20. század elején - a néptanítók enciklopédiája példája alapján (1911-1915)”. Magyar Pedagógia, 113, no. 2 (2013): 101-118.

Németh, András. “A reformpedagógia gyermekképe: A szent gyermek mítoszától a gyermeki öntevékenység funkcionális gyakorlatáig”. Iskolakultúra, 4, no 3 (2002): 21-32.

Németh, András. Weszely Ödön. Budapest: Országos Pedagógiai Könyvtár és Múzeum, 1990. 
Németh, András and Andrea Nagy. "Life Reform and Reform Pedagogy in Hungary”. Sodobna Pedagogika: Journal of Contenmporary Educational Studies, 70, no. 136 (2019): 192-205.

Németh, András and Béla Pukánszky. "Life Reform Efforts in the Austro-Hungarian Monarchy and Their Impact on Hungarian Cultural and Pedagogical Reforms”. Paedagogica Historica, 56, no. 4 (2019): 429-446.

Németh, András and Béla Pukánszky. "Magyar reformpedagógiai törekvések a XX. század első felében”. Magyar Pedagógia, 99, no. 3 (1999): 245-262.

Oelkers, Jürgen. "Psychologie, Pädagogik und Schulreform im 19. Jahrhundert". In Physiologie und industrielle Gesellschaft: Studien zur Verwissenschaftlichung des Körpers im 19 und 20. Jahrhundert, edited by Sarasin Phillipp und Tanner Jakob, 245-285. Frankfurt am Main: Surkamp, 1998.

Popkewitz, Thomas S. "The Double Gestures of Cosmopolitanism and Comparative Studies of Education”. In International Handbook of Comparatice Education, edited by Cowe, Robert and Kazamias, Andreas M., 385-401. London-New York: Springer, 2009.

Rieger-Ladich, Markus and Norbert Ricken. "Macht und Raum: Eine programmatische Skizze zur Erforschung von Schularchitekturen”. In Schularchitektur im interdisziplinären Diskurs. Territorialisierungskrise und Gestaltungsperspektiven des schulischen ildungsraums, edited by Böhme, Jeanette, 186-203. Wiesbaden: VS Verlag für Sozialwissenschaften, 2009.

Rißler, Georg, Bossen, Andrea, and Nina Blasse. "School as space: spatial alterations, teaching, social motives, and practices", Studia paedagogica, 19, no. 4 (2014): 146-159.

Sanda, István Dániel. “Az iskola-egészségügy és a tanulási környezet korszerüsödése Magyarországon - a szadforduló körüli évtizedekben”. Pedagógiatörténeti Szemle, 2, 3-4 (2016): 86-105.

Sanda, István Dániel. "Iskolaépület-típusok és életreform-motívumok a Bárczykorszak iskoláiban”. In Továbbélö utópiák - reformpedagógia és életreform a 20. század elsö felében.edited by Németh, András, Pukánszky, Béla and Pirka, Veronika, 214-302. Budapest: Gondolat Kiadó, 2014.

Sanda, István Dániel. “A pedagógiai terek vizsgálata. Különös tekintettel a XX. századi magyar iskolára”. Doctoral thesis. Budapest: ELTE PPK Neveléstudományi Doktori Iskola, 2009.

Sarasin, Philipp. Reizbare Maschinen: Eine Geschichte des Körpers 1765-1914. Frankfurt am Main: Shurkamp, 2001.

Sarasin, Philipp and Jakob Tanner. Physiologie und industrielle Gesellschaft: Studien zur Verwissenschftlichung des Körpers im 19. und 20. Jahrhundert. Frankfurt am Main: Shurkamp, 1998.

Schmidt, Rudolf. "Die geschichtliche Entwicklung des Volksschulbaus in Deutschland". Paedagogica Historica, 7, no. 1-2 (1967): 519-550. 
Schmidt, Rudolf. "Die geschichtliche Entwicklung des Volksschulbaus in Deutschland”. Paedagogica Historica, 8, no. 1-2 (1968): 153-193.

Seaborne, Malcolm Vivian John and Roy Lowe. The English school. Its architecture and organization. Toronto: University of Toronto Press, 1977.

Seaborne, Malcolm Vivian John. The English school: its architecture and organization 1370-1870. London: Routledge \& Kegan Paul, 1971.

Seaborne, Malcom Vivian John. Schools in Wales 1500-1900. A social and architectural history. Denbigh: Gee and Son, 1992

Sipos, András. "Bárczy István és Karl Lueger: két polgármester a századforduló Monarchiájában.”. In Urbanizáció a dualizmus korában: Konferencia Budapest egyesitésének 125. évfordulója tiszteletére a Budapesti Történeti Múzeumban, edited y Szvoboda Dománszky, Gabriella, 53-66. Budapest: Budapesti Történeti Múzeum, 1999.

Sipos, András. Várospolitika és városigazgatás Budapesten, 1890-1914. Budapest: Budapest Főváros Levéltára, 1996.

Skiera, Ehrenhard. Reformpädagogik in Geschichte und Gegenwart: Eine kritische Einführung. München und Wien: Oldenbourg, 2003.

Skiera Ehrenhard. "Über den Zusammenhang der Lebensreform und Reformpädagogik". In Reformpadagogik und Lebensreform in Mitteleuropa - Ursprünge: Ausprägung und Richtungen, edited by Skiera, Ehrenhard Németh, András, und Mikonya György, 22-47. Budapest: Gondolat Kiadó, 2006.

Smeyers, Paul and Marc Depaepe. "Exploring a Multitude of Spaces in Education and Educational Research". In Educational Research: the Importance and effects of Institutional Spaces, edited by Smeyers, Paul, Depaepe, Marc, and Keiner, Edwin, 1-10. London-New York: Springer, 2013.

Soja, Edward. Postmodern geographies: the reassertion of space in critical social theory. London: Verso, 1989.

Stanek, Łukasz. "Methodologies and Situations of Urban Research. Re-reading Henri Lefebvre's 'The Production of Space”. Zeithistorische Forschungen/ Studies in Contemporary History, 4, no. 3 (2007): 461-465.

Stroß, Annette. Pädagogik und Medizin: Ihre Beziehungen in "Gesundheitserziehung” und wissenschaftlicher Pädagogik 1779-1933. Weinheim: Beltz, 2000.

Tenorth, Heinz-Elmar. "Der Beitrag der Erziehungswissenschaft zur Professionalisierung pädagogischer Berufe”. In Professionalisierung pädagogischer Berufe im historischen Prozeß, edited by Apel, Hans Jürgen, Horn, Klaus-Peter, Lundgreen, Peter, und Sandfuchs, Uwe, 429-461. Bad Heilbrunn: Klinkhardt, 1999.

Vincze, Beatrix. “A földi édenhez vezető 'harmadik utas' elméleti és gyakorlati modellek a két világháború közötti Magyarországon”. In Továbbélö utópiák - magyar életreform-törekvések és nemzetközi recepciós hatások, edited by Németh András and Vincze Beatrix, 35-57. Budapest: Gondolat Kiadó, 2017. 
Vincze, Beatrix. “A kertmotívum Németh László pedagógiai és életreform koncepciójában”. In Gyermekek, tanárok, iskolák - egykoron és ma, edited by Németh, András and Pukánszky, Béla, 189-203. Budapest: Eötvös Kiadó, 2017.

Vincze, Beatrix. "Theoretische und praktische Modelle des zum irdischen Eden führenden 'Drittem Weges' in der Zwischenkriegszeit in Ungarn”. In Survival of Utopias - Weiterlebnede Utopien: Life Reform und Progressive Education in Austria and Hungary - Lebensreform und Reformpädagogik in Österreich und Ungarn, edited by Németh, András, Stöckl, Claudia and Vincze, Beatrix, 41-53. Franfurt am Main: Peter Lang Verlag, 2017. 